\title{
JUURNAL_RU
}

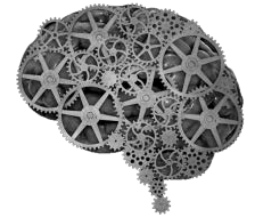

COMPANY GROUP "INTELLEKT"

\author{
Джалилова Б.А. \\ Российская академия народного хозяйства и государственной службы \\ при Президенте РФ \\ Москва, Россия
}

doi: 10.18411//j2016-9-2-04

idsp 000001: lj2016-18-2-04

\section{Органы, осуществляющие государственную поддержку и защиту института семьи в России и странах Европейского союза}

На данный момент теория права разработала множество определений дефиниции «государственный орган».

Большой юридический словарь определяет государственный орган как организованную часть государственного механизма, наделенную властными полномочиями, определенной компетенцией и необходимыми средствами для осуществления задач, стоящих перед государством на конкретном участке руководства обществом[1, с. 487].

Н.И. Матузов и А.В. Малько, говоря о государственном органе, фактически приравнивают его к органу государства, определяя его как «звено государственного аппарата, участвующее в осуществлении определенных функций государства и наделенное в этой связи властными полномочиями»[2, . 88].

С.В. Бошно дает похожее толкование, называя государственный орган «звеном (элементом) государства, участвующим в осуществлении функций государства и наделенное для этого властными полномочиями» [3, с. 433].

При этом она выделяет следующие признаки государственного органа:

- являются частью механизма государства, занимают в нем определенное место;

- состоят из государственных служащих, которые находятся в особых правоотношениях между собой и органами; 
- имеют внутреннее строение и состоят из подразделений, скрепленных единством целей, ради достижения которых они образованы, и дисциплиной, которую все служащие обязаны соблюдать;

- обладают компетенцией, т.е. властными полномочиями, состоящими из прав и обязанностей, определенного содержания и объема $[4$, с. 433].

Большой юридический энциклопедический словарь фактически несколько расширяет определение, данное С.В. Бошно: «государственный орган - составная часть (элемент) государственного аппарата, имеющая в соответствии с законом собственную структуру, определенные властные полномочия по управлению конкретной сферой общественной жизни, исполнение которых обеспечивается принудительной силой государства [5, с. 125].

Для того чтобы более полно изучить вопрос о государственных органах, необходимо так же обратиться к характерным чертам данного явления. Изучив выше данные определения, мы можем выделить следующие:

- в первую очередь, государственный орган наделен государственновластными полномочиями, которые позволяют ему решать определенные вопросы, а так же издавать акты, обязательные к исполнению другими государственными органами, должностными лицами и гражданами; обеспечивать исполнение этих актов.

Государственно-властные полномочия находят выражение в компетенции государственных органов, под которой следует понимать совокупность предметов их ведения и полномочий, которыми они наделены в отношении этих предметов ведения.

- - органы государства образуются в установленном государством порядке.

- - органы государства уполномочиваются государством осуществлять его задачи и функции.

- - органы государства действуют в установленном государством порядке.

- - и, наконец, каждый орган государства является составной частью единой системы органов власти Российской Федерации.

Исходя из данных характеристик, мы можем определить государственный 
орган как публично-правовую организацию, наделенную государственновластными полномочиями; образуемое и действующее в установленном государством порядке для осуществления его (государства) функций и задач, а так же являющееся составной частью единой системы органов государственной власти.

Органы государственной власти многообразны и могут быть разделены на виды по ряду оснований:

- по месту в системы разделения властей;

- по способу формирования состава государственного органа;

- по месту органов в иерархии власти;

- по первичной нормативной основе деятельности;

- по кадровому составу;

- по способу волеизъявления;

- по предмету регулирования и т.д.

В связи с тематикой работы мы остановим свое внимание на тех органах государственной власти, которые занимаются непосредственным осуществлением государственной политики семьи в Российской Федерации, осуществляют защиту и охрану института семьи.

В Российской Федерации нет специального органа исполнительной власти, который ведал бы исключительно вопросами государственной поддержки семьи, их целый комплекс.

Эксперты комитета социальной политики Европейского Союза называют нам следующие государственные органы Российской Федерации, чьи полномочия охватывают семейную политику: Министерство здравоохранения Российской Федерации, Министерство экономического развития Российской Федерации, Министерство образования и науки Российской Федерации, Министерство спорта Российской Федерации, Министерство культуры Российской Федерации, Министерство финансов Российской Федерации, Министерство труда и социальной защиты, Федеральное агентство по делам молодежи, а так же различные органы на уровне субъектов федерации [6].

С учетом межведомственного характера государственной поддержки семьи каждый государственный орган ответственен за реализацию какого-то определенного направления. 
Министерство здравоохранения совместно с Министерством труда и социальных отношений призваны обеспечить семьям с детьми возможность совмещения их семейных обязанностей с работой; обеспечить социальные гарантии для семей с детьми, а так же медицинскую помощь [7].

Министерство образования и науки Российской Федерации занимается вопросами обеспечения социальной поддержки для детей-сирот и детей, оставшихся без попечения родителей.

Министерство финансов, разрабатывая налоговую политику, уделяет внимание предоставлению налоговых льгот для семей с детьми, финансированию государственной поддержки семьи.

Остальные министерства по большей части исполняют вспомогательные функции [8].

Необходимо так же отметить, что в связи с тем, что в Конституции Российской Федерации предусматривается совместное ведение федерации и субъектов федерации по делам семьи (ст. 72), а так принимая во внимание огромное значение реализации государственной поддержки семьи, в некоторых регионах созданы специализированные органы субъекта федерации, отвечающие за семейную политику на данной территории (например, Департамент семейной и молодежной политики г.Москва).

Помимо органов, указанный в Буклете, вопросами государственной поддержки семьи ведает так же Пенсионный фонд Российской Федерации.

Именно при его участии осуществляется распоряжение средствами материнского (семейного) капитала.

Заявление о распоряжении подлежит рассмотрению территориальным органом Пенсионного фонда Российской Федерации в месячный срок с даты приема заявления о распоряжении со всеми необходимыми документами (их копиями, верность которых засвидетельствована в установленном законом порядке), по результатам которого выносится решение о распоряжении (ст. 8) [9].

В странах Европейского Союза так же не везде имеются специализированные органы, чья деятельность была бы посвящена исключительно семейной политике.

Например, в настоящее время в Греции обязанность по разработке мер семейной политики и их осуществления распределена между несколькими 
органами. Министерство народного хозяйства имеет специальный отдел по вопросам народонаселения и занятости. Фактически данный отдел осуществляет демографическую политику. Министерство здравоохранения обеспечивает социальное страхование, а так же занимается вопросами благополучия семей с детьми и выплаты им пособий. Министерство труда занимается родительскими и декретными отпусками.

Тем не менее, не все из перечисленных министерств в своей деятельности явно формируют понятие «семейной политики». Обычно они влияют на нее, занимаясь более общими вопросами здравоохранения, образования и т.д.

Однако в 2006 году законом 4354/2006 «Укрепление семьи и других положений» в Греции был создан специальный Национальный совет по делам семьи и народонаселения с правом совещательного и консультационного голоса в Парламенте, направленный на стимулирование общественного диалога по вопросам демографической политики. В том же году был основан Институт социальной демографии и исследований, занимающийся изучением демографических тенденций, а так же оценкой эффективности существующих мер семейной политики.

В Болгарии вопросами создания, реализации и контроля семейной политики занимается один орган - Министерство труда и социальной политики. С конца 2005 года в нем существует Дирекция по демографической политике и равным правам (гендерное равенство), осуществляющая следующие полномочия:

- участвует в разработке методологии и методики для мониторинга и исследования демографических и гендерных процессов;

- разрабатывает меры, программы и проекты в области демографического развития страны, поддержки семей с детьми и предоставления равных возможностей для мужчин и женщин;

- разрабатывает эффективные механизмы для улучшения качества оценки демографических показателей страны;

- анализирует эффективность реализации «Национальной стратегии демографического развития Республики Болгария 2005-2020 гг.» и ежегодного плана действий в соответствии с ним [10].

В Хорватии Правительство Республики разделило полномочия, касающиеся вопросов семьи между Министерством по делам семьи, делам ветеранов и 
солидарности поколений и Министерством здравоохранения и социального обеспечения.

В Чехии благополучие семьи и детей подпадает под ведомство Министерства труда и социальных дел. Оно несет ответственность за проблемы семьи на государственном уровне, подразделяя их на два блока: блок социальной и правовой защиты детей; блок семейной политики. Второй блок занимается подготовкой законодательных программ по улучшению положения семей. Помимо этого его члены участвуют в подготовке различных проектов, касающихся семьи: конференциях, саммитах, встречах, обсуждениях законопроектов и др.

Кроме того, Министерство труда и социальных дел Чешской Республики включает в свой состав Правительственный совет, занимающийся вопросами предоставления равных возможностей для мужчин и женщин во всех сферах общественной жизни. При этом следует отметить, что данные государственные органы являются лишь совещательными.

В Эстонии с 2007 года ответственность за национальную семейную политику несет Министерство социальных дел. А именно блок семейной политики в Департаменте по вопросам гендерного равенства, находящийся в непосредственном подчинении у заместителя Генерального секретаря по семейной и социальной политике.

Вопросами семейной политики занимается небольшой аппарат, включающий в свой состав всего двадцать экспертов, постоянно следящих за воздействием различных законодательных инициатив на семейную политику и благополучие семей [11].

В Германии на федеральном уровне вопросами семьи ведает Федеральное министерство по делам семьи, пожилых граждан, женщин и молодежи. На уровне субъектов федерации (земель) существуют свои отдельные государственные органы [12].

В Венгрии Министерство социальных дел и труда отвечает за планирование и подготовку правовых актов, связанных с семейной политикой. Так же в Венгрии существует специализированный Институт социальной политики и труда, в обязанности которого входят разработка широкого спектра задач, связанных с координацией и поддержкой семьи, молодежи, социальной политики [13]. 
Данный Институт участвует в различных международных конференциях и саммитах, посвященных вопросам семьи, поддерживает связь с различными зарубежными учреждениями, занимающимися вопросами семьи (особенно странчленов ЕС), и передает полученную информацию и свои исследования в Министерство социальных дел и труда.

В Ирландии, как и в ряде других государств, нет одного органа, отвечающего за семейную политику. Данному вопросу уделяют свое внимание несколько департаментов.

- Департамент социальных дел и семьи ответственен за уплату социальных пособий семей с детьми.

- Департамент образования и науки несет ответственность за предоставление образования детям из социально незащищенных слоев общества; создает меры для включения в образовательный процесс детей с особыми образовательными потребностями.

- Департамент здравоохранения отвечает за услуги по поддержке семей. Например, услуги по уходу за младенцами, по поддержке детей с ограниченными возможностями, при усыновлении детей и т.д.

- Департамент юстиции, равноправия и правовой реформы несет ответственность за интеграцию в существующую систему семейной политики иммигрантов и их детей.

- Департамент предпринимательства, торговли и занятости ответственен за реализацию механизма по оказанию помощи работникам в сочетании трудовой занятости с другими аспектами их жизни, в том числе семейной [14].

В Ирландии так же существует достаточно разветвленная сеть негосударственных учреждений, консультирующих семьи по различным вопросам: планирование беременности, развод и др. (например, Ирландская ассоциация планирования семьи) [15].

В Латвии вопросами семейной политики занимаются два государственных органа: Министерство по делам детей и семьи и Министерство благосостояния.

Министерство по делам детей и семьи является ведущим государственным учреждением в области защиты прав детей, семьи и молодежи. Его основными функциями являются: 
- обеспечение реализации государственной политики в области детей и семьи;

- координация семейной и детской политики;

- производство нормативных актов, связанных с детьми и семейной политикой;

- сотрудничество с другими государственными органами, органами самоуправления, негосударственными организациями, осуществляющими свою деятельность в сфере, касающейся детей и семьи.

Министерство благосостояния в свою очередь отвечает за разработку и координацию политики труда, социальной защиты и гендерного равенства. Так же Министерство благосостояния осуществляет политику в области предоставления государственных социальных пособий.

В Литве с 2009 года функции по осуществлению семейной политики возложены на отдел по делам семьи, включенный в систему подведомственных Министерству по делам семьи и социальной политики подразделений. Одной из важнейших задач данного отдела является устранение препятствий для благоприятного сочетания семейной и трудовой жизни.

В Польше основным органом, несущим ответственность за реализацию семейной политики, является Министерство труда и социальной политики. Данное министерство при осуществлении своей деятельности координирует свои действия и сотрудничает с Министерством образования, Министерством здравоохранения, Министерством финансов и Министерством юстиции.

В Словакии в качестве главного координирующего органа по вопросам семьи выступает Министерство юстиции Словацкой Республики. Помимо этого часть полномочий принадлежит Министерству финансов и Министерству образования.

В Словении в структуру Министерства труда, семьи и социальных вопросов входит Управление по делам семьи, отвечающее за семейную политику, политику государства в отношении брака, усыновления детей и т.п.

В дополнение к этому Управление по делам семьи так же:

- готовит подзаконные акты в рамках своей компетенции; 
- является апелляционным органом в вопросах, находящихся под его юрисдикцией;

- является посредническим органом между Республикой Словенией и органами других государств в определенной категории судебных дел, когда должник живет вне территории Словении [16].

В Финляндии Министерство социального обеспечения и здравоохранения руководит политикой и развитием системы услуг в области семенной политики, а также координирует ее функционирование. Совместно с Государственным советом и Парламентом страны Министерство определяет ключевые направления развития государственной политики в области социальной защиты и здравоохранения, подготавливает законодательные акты и основные реформы.

В Финляндии так же действует Управление социального обеспечения «Kela», несущая ответственность за претворение в жизнь закрепленной законом базовой социальной защиты проживающих в Финляндии людей. Она выплачивает родителям ребенка суточные за период родительского отпуска, а также производит выплаты по иным семейным льготам. Для получения льгот необходимо подать заявление в «Kela» [17, c. 5].

Исходя из выше написанного, мы можем сделать следующие выводы:

1. Далеко не во всех странах вопросами семейной политики ведает один специализированный государственный орган. Чаще всего это целый комплекс органов, которые образуют единую систему, в которой каждый отдельный механизм отвечает за свою область задач. Именно так это происходит, например, в Российской Федерации. Вопросами семейной политики в России занимаются: Министерство здравоохранения, Министерство труда и социальных отношений, Министерство образования и науки, Министерство финансов, Министерство экономического развития, Министерство спорта, Министерство культуры, Федеральное агентство по делам молодежи, Пенсионный фонд, а так же различные органы на уровне субъектов федерации.

2. В связи с тем, что некоторые государства из списка изученных нами являются федерациями, часто вопросами семейной политики занимаются не только федеральные органы, но так же органы 
субъектов федерации и/или местного самоуправления (например, Департамент семейной и молодежной политики г. Москвы).

3. Ряд государств наделяет правом регулировать отношения, возникающие в рамках семейной политики, не только государственные органы, но и различные негосударственные некоммерческие организации (например, Ирландская ассоциация планирования семьи).

4. Помимо этого так же некоторые страны-члены Европейского Союза создают при государственных органах различные исследовательские институты, призванные помочь им в разработке более эффективных методов регулирования вопросов семейной политики, что можно отметить как весьма прогрессивный шаг. 


\section{Литература:}

1. 1.Большой юридический словарь , 3-е изд., доп. и перераб. / Под ред. проф. А.Я. Сухарева. М., 2010. T. VI, С.487.

2. Матузов Н.И., Малько А.В. Теория государства и права: учебник. - 3-е изд. М., 2009. С. 88.

3. Бошно С.В. Теория права и государства: учебник / Бошно С.В. - 2-е изд., пераб. и доп. М., 2011. С. 433.

4. Бошно С.В. Теория права и государства: учебник / Бошно С.В. - 2-е изд., пераб. и доп. М., 2011. С. 433.

5. Барихин А.Б. Большой юридический словарь. 2-е изд., перераб. и доп. М., 2008. C. 125.

6. 6.Family Policy in Council of Europe Member States / Two expert reports commissioned by the Committee of Experts on Social Policy for Families and Children

URL: http://www.leavenetwork.org/fileadmin/Leavenetwork/Links_publications/Fami ly_Policy_in_Council_of_Europe_member_states_en.pdf

(датаобр. 29.07.2016).

7. 7.Family Policy in Council of Europe Member States / Two expert reports commissioned by the Committee of Experts on Social Policy for Families and Children

URL: http://www.leavenetwork.org/fileadmin/Leavenetwork/Links_publications/Fami ly_Policy_in_Council_of_Europe_member_states_en.pdf (датаобр. 29.07.2016).

8. Family Policy in Council of Europe Member States / Two expert reports commissioned by the Committee of Experts on Social Policy for Families and Children URL: http://www.leavenetwork.org/fileadmin/Leavenetwork/Links_publications/Fami ly_Policy_in_Council_of_Europe_member_states_en.pdf 
29.07.2016).

9. Федеральный закон от 29.12.2006 № 256-Ф3 "О дополнительных мерах государственной поддержки семей, имеющих детей" (в ред. от 08.03.2015, с изм. от 06.04.2015) Официальный интернет-портал правовой информации (ГСПИ) http://www.pravo.gov.ru/ (дата обр. 11.04.2015).

10. Family policy: institutional framework and objectives URL: http://www.coe.int/t/dg3/familypolicy/Source/1_1_i\%20Government\%20bodies .pdf (датаобр. 29.07.2016).

11. Family Policy in Council of Europe Member States / Two expert reports commissioned by the Committee of Experts on Social Policy for Families and Children

URL: http://www.leavenetwork.org/fileadmin/Leavenetwork/Links_publications/Fami ly_Policy_in_Council_of_Europe_member_states_en.pdf (датаобр. 29.07.2016).

12. 12.Family Policy in Council of Europe Member States / Two expert reports commissioned by the Committee of Experts on Social Policy for Families and Children

URL: http://www.leavenetwork.org/fileadmin/Leavenetwork/Links_publications/Fami ly_Policy_in_Council_of_Europe_member_states_en.pdf (датаобр. 29.07.2016).

13. Family Policy in Council of Europe Member States / Two expert reports commissioned by the Committee of Experts on Social Policy for Families and ChildrenURL:

http://www.leavenetwork.org/fileadmin/Leavenetwork/Links_publications/Fami ly_Policy_in_Council_of_Europe_member_states_en.pdf (датаобр. 29.07.2016).

14. Family Policy in Council of Europe Member States / Two expert reports commissioned by the Committee of Experts on Social Policy for Families and Children

URL: 
http://www.leavenetwork.org/fileadmin/Leavenetwork/Links_publications/Fami ly_Policy_in_Council_of_Europe_member_states_en.pdf (датаобр. 29.07.2016).

15. Family Policy in Council of Europe Member States / Two expert reports commissioned by the Committee of Experts on Social Policy for Families and Children

URL: http://www.leavenetwork.org/fileadmin/Leavenetwork/Links_publications/Fami ly_Policy_in_Council_of_Europe_member_states_en.pdf (датаобр. 29.07.2016).

16. Family Policy in Council of Europe Member States / Two expert reports commissioned by the Committee of Experts on Social Policy for Families and ChildrenURL:

http://www.leavenetwork.org/fileadmin/Leavenetwork/Links_publications/Fami ly_Policy_in_Council_of_Europe_member_states_en.pdf (датаобр. 29.07.2016).

17. Брошюра Министерства социального обеспечения и здравоохранения. Политика семьи и детей в Финляндии. Министерство социального обеспечения и здравоохранения. Хельсинки. 2013. С. 5. 